Available online at www.jmle.org

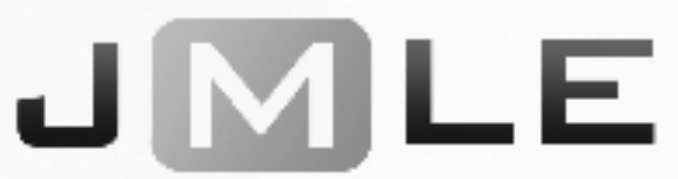

The National Association for Media Literacy Education's Journal of Media Literacy Education 10 (3), 175 - 179

\title{
BOOK REVIEW \\ Exploring Critical Digital Literacy Practices: Everyday Video in a Dual Language Context
}

\author{
Reviewed by \\ Lucie Roemer \\ Charles University, Czech Republic
}

Exploring Critical Digital Literacy Practices: Everyday Video in a Dual Language Context by Jessica Zacher Pandya. 2018. New York and London: Routledge.

The biggest fear of my aunt, an experienced high school teacher, is going to the local sauna and meeting one of her students there. So, to keep her distance, she, and most of her colleagues, never go. In the book Exploring Critical Digital Literacy Practices: Everyday Video in a Dual Language Context, Jessica Zacher Pandya decided not only to enter the sauna but also to leave all the clothes in the locker, turn the temperature high and to talk to her readers with unusual honesty.

Pandya, who is the Chair of the Liberal Studies Department at California State University, has been investigating digital video production at schools longitudinally. Exploring Critical Digital Literacy Practices: Everyday Video in a Dual Language Context draws on this experience and presents the findings from her project in a Californian, dual language, under-resourced charter school. Working with 8-10-year-olds, the professor explored the ways children interrogate their worlds, the kinds of identities they craft, and the language and literacy learning practices that emerge from digital video production. The project was funded by the Foundation for Child Development.

Pandya commits axiologically to redistributive, transformative social justice theory, seeing an analogy between the literacy injustices research and the inquiry into the "political economic restructuring" such as redistributing income or "transforming other basic economic structures" (Fraser, 1997: 15). Further, inspired by Eve Tuck, she believes in the desire-centered research, believing that academia 
must shift "the discourse away from damage and toward desire and complexity" (Tuck, 2009: 422). She believes that, rather than focusing on what damage has been done to which community, research should ask how damage has been overcome or resisted. She also largely works with the concept of critical digital literacy practice, defined by Allan Luke as "a process of naming and renaming the world, seeing its patterns, designs and complexities, and developing the capacity to redesign and reshape it" (Luke, 2014:29).

She takes the grounded theory approach and uses the design-based research method. We follow the researcher's backward mapping of an initially conventional social studies project, introducing video production to an elementary school. Pandya's team helps the students produce videos which tell about their life stories, birds or the Civil Rights movement. However, during the project, the Esperanza school appears under the threat of closure. At this moment, the students start producing videos to fight for or against the closure of their school. The team creates a multimodal transcript of each of the videos. Further, surveys and interviews with the students and teachers, as well as field notes are used for the research.

The chapters of the book are grouped around the following topics: theoretical and practical considerations regarding the digital video at school; digital video projects at Esperanza; examining, and working with, children's design sensibilities, activism and audience in school video projects; and, finally, a concluding reflection on the project.

Pandya offers the readers a uniquely open, honest, self-critical teacher's, or researcher's, roadmap for practice with a rich theoretical background and references to both the modern (Luke, 2014) and traditional sources (Freire, 1970). She does not hesitate to share the failures occurring in the school and the community, but also with her research team. For example, she writes that her field notes are filled with phrases like, "Still not a lot of time to jot notes" (p. 15), and she admits that eventually, the field notes became very scattered. Or, in a very critical passage about the technical equipment available at the school, she mentions a relatively shocking fact that "for some of the kids, this was the first time ever using a computer" (p. 45).

There are numerous case studies presenting an introduction of an innovative teaching method (Cohen, 2001; Cheung \& Xu, 2014; Parks, 2009), but they usually have the form of research articles, rather than the sustained rich description possible in books. Also, Pandya researched a whole school, not just a classroom, and the project went for 4 years, not just a unit, or a semester.

She uses the first person and writes in a very lively, easy-to-read language, though keeping the high academic standard at the same time.

Pandya takes a deeply respectful approach towards the students, teachers, and the community. Also, she uses more than half a page to name all the members of the team, mostly her undergraduate students, though many were only involved shortly. "When I write 'we' in these pages, it is to honor the work and analysis we have done together," (p. 5).

At some parts, one might have the impression that the friendly chat in the sauna has gone too far and the researcher has lost any distance from the school as research subject. During the last year of the project, after which the school was 
eventually closed, Pandya's child actually attended Esperanza and she turned into an engaged parent. For example, Pandya presents her letter to the state, which includes passages such as, "The school means so much to my child," (p. 85). The author also admits, "I was frightened for the future of the school community I had come to admire," (p. 102). However, in the context of the design based research method, which is largely based on the time and interpersonal commitments, the very personal approach can be understood.

By providing the students with the tools of video production and with the experience of an active citizen campaign, Pandya also contributes to the further development of the citizenship model of media literacy education (Hobbs, 1998).

The theoretical, methodological and practical parts correspond. Pandya enriches the literacy theories with numerous observations, such as: "The vast majority of children used literal, representative images that matched the words they were speaking ... however, within and across videos, children experimented with images, used metaphorical images," (p. 11); "The videos helped students develop in their second language," (p. 48); references to how the students cared deeply about their families and their audiences and preferred representation to aesthetics (e.g., p. $65)$; and, finally: "If these projects taught me only one thing, ... it is that children can, and will, make powerful arguments about issues that matter to them to external audiences," (p.100). Nevertheless, several research questions remain unanswered, especially, "How does being/becoming -or not being/becoming- American fit into those [video-narated] identities?" (p. 12).

Also, a large part of the data collection included interviews with teachers and students, but the readers only see a few results from the interviews with teachers, and none of those with the students. Instead, Pandaya often presents the reader with her feelings, impressions, or thoughts, which could probably be supported by the data from these interviews, but they are not. For instance, she mentions that the official explanation of the lack of experience with technologies in the classes is caused by not having enough resources. But then she writes, "But I also thought that some of the lack was due to a lack of expectation that teachers would use technology," (pp. 46-47). But such information probably could have been verified in the interviews.

The author chose to do her research in a dual language charter school, which makes the study very interesting and highly relevant for anyone exploring digital literacy at other schools with students with specific needs or from economically disadvantaged families. The challenges of working in dual language are described; however, there is very little reflection on the work with students of a charter school in general. Also, the situation of the school becomes very specific as it faces the closure, and though it is interesting, it leads the research somewhat away from the original aim, away from the literacy practices and more to a defense of the school itself (this occurs especially in chapter 5).

A few minor issues in the style of the text detract from the overall quality. The book includes several illustrations - photos from the classes, multimodal transcript protocols or images from the student's videos. These make the text more lively, but they are unfortunately often unsharp (Figure 2.1 on page 22), too small 
(the multimodal script on page 9, Figure 1.1, is almost unreadable), or they are incomplete (Table 3.1 on page 44 is missing the legend for the numbering of the projects).

The text is also rather U.S.-audience-centered, as Pandya uses several country-specific terms without explaining them, such as the "California Common Core Standards" (p. 19), "grade K-8" (p. 44), or "IEP-labeled disabilities," (p. 66) (which are explained, but half a page later). And finally, the book is formed largely by extremely detailed descriptions of the videos or the stories of the individual children, which are interesting, but less detail about the individuals and more induction and analysis of the project as a whole (or its parts, but not only individual videos) would be perhaps more useful. Despite these minor critical observations, Exploring Critical Digital Literacy Practices: Everyday Video in a Dual Language Context presents a fresh wind in the studies of literacy.

The practical and informative analysis of making videos in schools might be of international interest to both digital literacy teachers and researchers. As Luke puts it in the preface: "These students' digital productions would fit well in many Queensland schools, (...) they would likely find a place in the current curriculum reforms in Finland." (Luke, xi). And the author of this review adds that it would be also relevant in the Czech Republic, where digital video production in schools is at its beginning.

Finally, Pandya touches one of the core transnational educational problems the outdatedness of many school curricula and the fascination with the standardized testing, which is often an obstacle for the development of more innovative and creative literacy projects. If more teachers/researchers dared to speak about these issues with such sauna-like openness like Pandya, the literacy practices at schools might be developing at a much faster scale.

\section{REFERENCES}

Cohen, C. (2001). Case study: Establishing media literacy in a Catholic school setting. Center for Media Literacy [available at http://www.medialit.org/readingroom/case-study-establishing-media-literacy-catholic-school-setting] (viewed 2. 5. 2018)

Cheung, C.K., Xu, W. (2014). Promoting media literacy education in China: a case study of a primary school. International Journal of Adolescence and Youth [available at https://www.tandfonline.com/doi/full/10.1080/02673843.2013.821078] (viewed 6. 3. 2018).

Fraser, N. (1997) Justice interruptus. New York. NY: Routledge.

Freire, P. (1970) Pedagogy of the oppressed. New York: Herder and Herde.

Hobbs, R. (1998). Building citizenship skills through media literacy education. In: M. Salvador and P. Sias (Eds.), The public voice in a democracy at risk. Westport, CT: Praeger Press, pp. 57-76. [available at http://www.medialit.org/readingroom/building-citizenship-skills-through-media-literacy-education] (viewed 6. 12. 2017). 
Luke, A. (2014) Defining critical literacy. In: J. Pandya \& J. Ávila (Eds.), Moving critical literacies forward. A new look at praxis across contexts (pp. 19-31). New York, NY: Routledge.

Parks, M. R. (2009) Middle school technology and media literacy: An action research case study. Thesis, Georgia State University [available at https://scholarworks.gsu.edu/wsi theses/17] (viewed 6. 3. 2018).

Tuck, E. (2009) Suspending damage: A letter to communities. Harvard Educational Review, 79, 409-427. 